\title{
Histopathological changes in diseased and treated catfish (Clarias gariepinus) by ciprofloxacin and clove oil
}

\author{
S.S. Abd El-Salam ${ }^{*}$, M.F. Ghaly ${ }^{2}$, D.M. Baraka ${ }^{1}$, S.H. Mahmoud ${ }^{3}$ \\ and A.A. El-Makhzangy ${ }^{3}$
}

\footnotetext{
${ }^{1}$ Botany Department, Faculty of Science, Benha University, Egypt, ${ }^{2}$ Botany Department, Faculty of Science, Zagazig University, Egypt, ${ }^{3}$ Animal Health Research Institute, Zagazig, Egypt

*Corresponding author: email: Dr.soheir_saad@yahoo.com, Phone: +2/01067140872
}

(Received October 15, 2017; Accepted October 27, 2017)

\begin{abstract}
Bacteria pathogens may cause a serious loss in aquaculture and also health hazards to humans. On the basis of biochemical characteristics and API-20E system, all isolates of pathogens from diseased fish were identified as Aeromonas spp, the most predominant bacterial species were $A$. sobria $46.7 \%$, A caviae $19.03 \%$, A. jandaei $8.6 \%$ and $A$. veronii $8.6 \%$. One hundred and twenty Nile catfish Clarias gariepinus were divided into four equal groups $(1,2,3$ and 4$)$ were challenged with Aeromonas sobria which predominant isolates, Gp. (1) was challenged only, while Gps. (2, 3 and 4) were treated after challenged with ciprofloxacin, clove extract and ciprofloxacin and clove extract in combination, respectively. The antibacterial activity of antibiotic and clove extract in their therapeutic doses decrease the mortality rate as (20,16 and 13\%) respectively compared with non-medicated Gp. (1) which recorded mortality 83\%. Internal signs of infection with Aeromonas sobria in African catfish (Clarias gariepinus) include congestion of the hepatic blood vessels, areas of coagulative necrosis in the liver and hydropic degeneration of renal tubules according to the histopathological examination. In-vivo the combination of ciprofloxacin and clove extract was the choice as alternative bacterial therapeutic agent in infected Clarias gariepinus with Aeromonas sobria. Moreover histopathological changes have been widely used as biomarkers in the evaluation of the health of fish exposed to contaminants.
\end{abstract}

Keywords: Aeromonas, Catfish, Ciprofloxacin, Clove, Histopathological Available online at http://www.vetmedmosul.org/ijvs

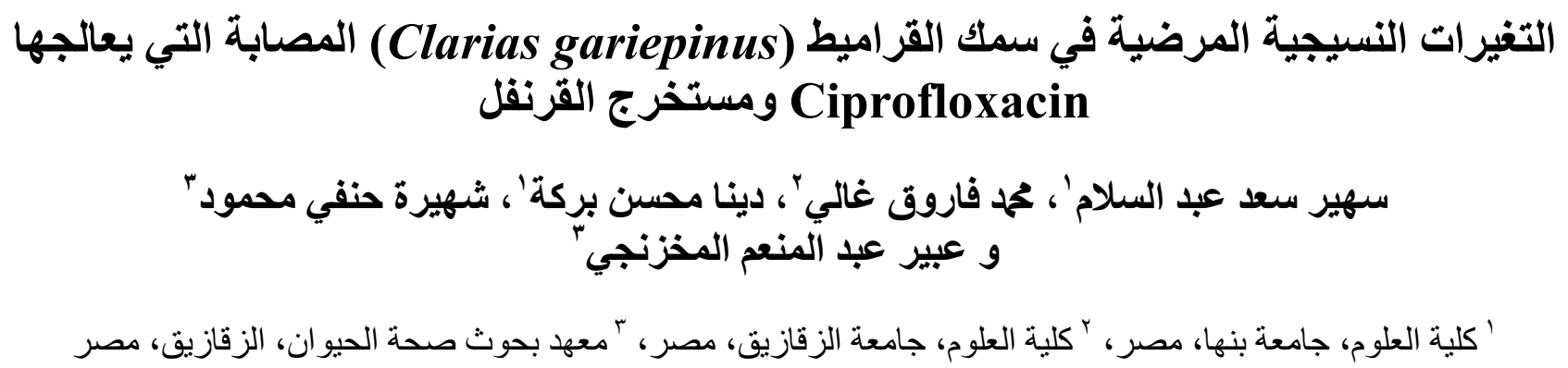

البكتريا المسببة للمرض ادت الى خسارة فادحة في الاستزراع المائي للأسماك وكذلك المخاطر الصحية على البشر. تم تحديد البكتريا

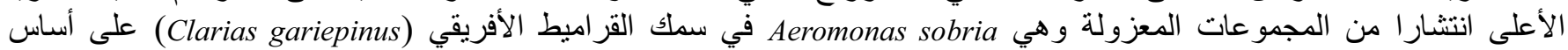

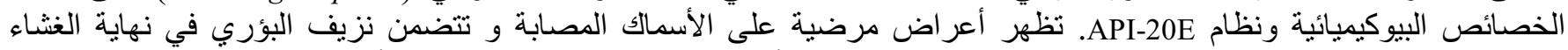

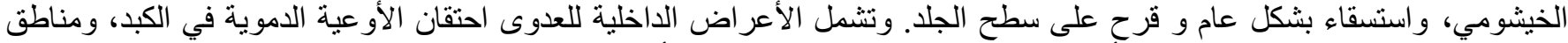
التليف في الكبد و التحلل المائي في الأنابيب الكلوية وفقا للفحص النسيجي. أستخدت التغيرات المرضية النسيجية على نطاق واسع 


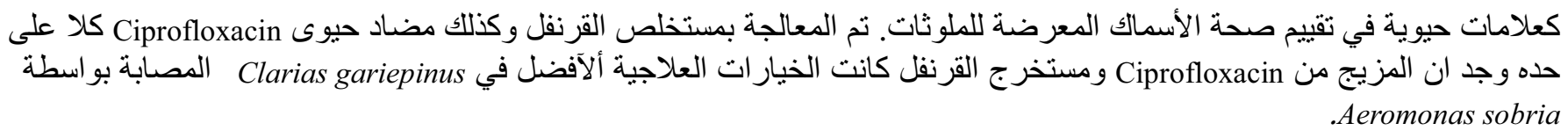

\section{Introduction}

The most important pathogen in channel catfish is Aeromonas spp, which is the primary causative agent of Motile Aeromonas septicemia (MAS) and can infect multiple fish species including tilapia, catfish, gold fish and common carp (1). Motile Aeromonas Septicemia is considered one of the most common diseases of cultured warm-water fish and widely distributed in food, drinking water and environment. (2). (3) noticed that the dominant strain at the farm during all four seasons was Aeromonas sobria. A. sobria was detected in $100 \%$ of intestinal samples from diseased trout. It was reported that epizootic ulcerative syndrome (EUS) caused by Aeromonas sobria resulted in great damage in fish farms (4). Aeromonas sobria was also the causative agent of disease in the farm of perch, Perca fluviatilis L, in Switzerland (5).

Chronic infections could lead to ulceration, inflammation and dermal lesions with focal hemorrhages where (6) and but during acute septicemia, the liver and kidney are the common target organs (7). In human, Aeromonas species cause diarrhea, gastroenteritis and extraenteritic conditions such as septicemia, wound infection, endocarditis, meningitis and pneumonia (8). Considering the susceptibility of fish to various potential stressors, it would be advisable to conduct regular health studies on the fish.

The isolated A.sobria of fish was sensitive to Vofloxacin, Norfloxacin, Rifampicin, Ciprofloxacin and Leucomycin (9). Also, (10) confirmed that none of the Aeromonas strains were resistant to Streptomycin, Ciprofloxacin and Nalidixic acid. (11) demonstrated that clove oil could reduce total bacterial counts in water and muscle of fish toxicities by cadmium, also inhibited the growth of Pseudomonas spp and Aeromonas spp. (12) concluded that clove oil was found to be in effective antioxidant in different in-vitro assays including reducing power. 2, 2-diphenyl-1-picrylhydrazyl (DPPH) radical, 2, 2'-azino-bis(3-ethylbenzothiazoline-6-sulphonic acid (ABIS) radical and superoxide anion radical scavenging, it can be used for preventing lipid oxidation in food and pharmaceutical products retarding the formation of toxic oxidation products.

The present investigation was planned to study the symptoms and the histopathological alterations of Aeromonas of infection in African catfish (Clarias gariepinus) collected from different localities in Sharkia governorate of Egypt.

\section{Materials and methods}

\section{Fish Collection}

One hundred and half (150) clinically healthy Clarias gariepinus were collected randomly with an average body weight (100-150 gm) and length $(20-22 \mathrm{~cm})$. Fish were kept in glass aquaria $(100 \mathrm{x} 50 \mathrm{x} 50 \mathrm{~cm})$ and supplied with chlorine free water at $25^{\circ} \pm 1^{\circ} \mathrm{C}$ with continuous aeration using electric air pumping compressors (RINA, Italy).

\section{Bacterial isolation and identification}

Under aseptic conditions, samples were collected from (liver, kidney and spleen) of Clarias gariepinus were collected from different localities in Sharkia Governorate. Samples were transferred to the laboratory and subjected to bacteriological examinations and then cultivated on Tryptic Soya agar (TSA) and incubated at $25^{\circ} \mathrm{C}$ and $\mathrm{PH} 7.3 \pm 0.2$ for 24 hours. The separated colonies were picked up and inoculated into Rimler-Shotts agar (RSA) plate for further identification (13). Biochemical tests were carried out according to (14) and API-20E strips (BioMerieux) were used as confirmatory identification.

\section{Pathogenicity test}

Five hundred and seventy of apparently healthy Clarias gariepinus (125 $\pm 5 \mathrm{~g}$ average body weight) were collected randomly to study the experimental infection of some bacterial isolates of A. sobria, A. jandaei, A. caviae and A. veronii were isolated from naturally infected fish. The fish were acclimated for two weeks, and then divided into 19 equal groups, each group in three replicates (each 10 fish). Groups (1-9) were injected intra-peritoneal with $0.2 \mathrm{ml}$ of $10^{10}$ A. sobria cells of different isolates. Groups (10- 12) were injected with $0.2 \mathrm{ml}$ of $10^{10}$ A. caviae cells. Groups (1315) were injected with $0.2 \mathrm{ml}$ of $10^{10} \mathrm{~A}$. jandaei cells. Groups (16- 18) were injected by $0.2 \mathrm{ml}$ of $10^{10}$ A.veronii cells. Groups (19) were injected with $0.2 \mathrm{ml}$ sterile saline $(\mathrm{NaCl}$ $0.85 \%$ ) as control (15). All experimentally injected fish were observed daily for 3-5 weeks to record any clinical signs, mortalities, abnormalities and specimens were seeded for bacterial re-isolation as determined by (16).

\section{Effect of ciprofloxacin and clove oil on mortality rate (\%) of experimentally infected Clarias gariepinus with $A$. sobria}

To determine in vivo efficacy of ciprofloxacine and clove extract against Aeromonas sobria infection, 120 Nile catfish (C. gariepinus) were divided into four equal groups each of 30 . They were kept in well aerated glass aquaria 
measuring $100 \mathrm{x} 50 \mathrm{x} 50 \mathrm{~cm}$ to be acclimated on dechlorinated tap water for 50 days. Group 1: Fish inoculated intra-peritoneal (IP) with $0.2 \mathrm{ml}$ of 24 hours broth culture of A.sobria $\left(2.5 \times 10^{8}\right)$ cell $/ \mathrm{ml}$ and kept without medication (positive control). Group 2: The same of experimentally infected fish were treated with therapeutic dose of ciprofloxacin $(25 \mathrm{mg}$ / liter of water). Group 3: The same of experimentally infected fish were treated with therapeutic dose of clove oil $(13.25 \mu 1)$. Group 4: The same of experimentally infected fish were treated with therapeutic dose of both ciprofloxacin and clove oil.

\section{Histopathological examination}

For histopathological studies, tissue specimens were obtained from liver and kidney. The tissue specimens were fixed in $10 \%$ natural buffered formalin. Dehydration and infiltration of tissue were carried on using automatic tissue processor. Samples were embedded in paraffin and sectioned using rotary microtome (4 to $5 \mu \mathrm{m}$ ) and stained with Hematoxylin and Eosin (H\&E) according to the method described by (17).

\section{Result and Discussion}

Mortality rate was among the experimentally infected C.gariepinus with $0.2 \mathrm{ml}$ of saline containing $10^{10}$ cells $/ \mathrm{ml}$ of $24 \mathrm{hrs}$ A. sobria by intra-peritoneal rout were showed in Table (1). The mortality rate was differed from $20-100 \%$ of A. sobria isolates. While, the mortality rate was recorded with one isolate of $A$. jandaei $90 \%$ and two isolates of $A$. veronii $20 \%$ also mortality rate in $A$. caviae range from $10-80 \%$. Fish were found dead without any clinical signs while the postmortem findings were congestion in liver and kidneys with hemorrhages in the intestine. A. jandaei, $A$. veronii and $A$. caviae were re-isolated from different organs of moribund and recently dead fish.

Table 1: Mortality rate of C.gariepinus due to experimental infection intra-peritoneal with $0.2 \mathrm{ml} \mathrm{of} 10^{10}$ cells $/ \mathrm{ml}$ of different isolates of Aeromonas spp

\begin{tabular}{|c|c|c|c|c|c|c|c|c|c|c|c|c|c|c|c|c|c|c|c|}
\hline \multirow{2}{*}{ Items } & \multicolumn{19}{|c|}{ Bacterial isolates } \\
\hline & \multicolumn{9}{|c|}{ A. sobria } & \multicolumn{3}{|c|}{ A. caviae } & \multicolumn{3}{|c|}{ A.jandaei } & \multicolumn{3}{|c|}{ A.veronii } & Control \\
\hline Gro & 1 & 2 & 3 & 4 & 5 & 6 & 7 & 8 & 9 & 10 & 11 & 12 & 13 & 14 & 15 & 16 & 17 & 18 & 19 \\
\hline No of fish & 30 & 30 & 30 & 30 & 30 & 30 & 30 & 30 & 30 & 30 & 30 & 30 & 30 & 30 & 30 & 30 & 30 & 30 & 30 \\
\hline Mortality & 90 & 100 & 100 & 90 & 100 & 60 & 100 & 20 & 90 & 0.0 & 80 & 10 & 0.0 & 0.0 & 90 & 0.0 & 20 & 20 & 0.0 \\
\hline
\end{tabular}

Ciprofloxacin, clove extract and both of them As shown in table (2) successfully to reduced mortality rate from $83 \%$ in GP (1) to $20 \%, 16 \%, 13 \%$ respectively by the $5^{\text {th }}$ day post treatment with extract and ciprofloxacin while it completely disappeared by $7^{\text {th }}$ day of treatment. The fish infected with $A$. sobria then treated by ciprofloxacin group (2) showed few symptoms as dorsal hemorrhages and depression during the $1^{\text {st }}$ week but some fish showed recovery at the end of experimental period.

Fish infected with $A$. sobria then treated by clove extract group (3) showed lesions but they were milder than those in group (1). Fish infected with $A$. sobria and treated with both Ciprofloxacin and Clove extract (4) The lesions of such group were ameliorated than those described with the infected group (1), treated with Clove extract group (3), or with Ciprofloxacin group (2) alone.

\section{Histopathological changes}

The clinical signs and the histopathological examination were recorded in the four groups.

\section{Group1: Catfish infected with $A$. sobria and non-treated}

The liver revealed irregular areas of coagulative necrosis (Fig 1, A). Congestion of hepatic blood vessels with few leukocytic infiltration and hemorrhage especially around the hepatoportal anastomosis (Fig 1, B). The kidney showed coagulative necrosis in the tubules, congestion of the blood vessels and depletion of the hemopoietic elements (Fig 2).

Table 2: The effect of ciprofloxacin $(25 \mathrm{mg} / \mathrm{L})$ \& clove oil $(13.25 \mu / \mathrm{L})$ on mortality rate (\%) of experimentally infected Clarias gariepinus with $A$. sobria

\begin{tabular}{lccc}
\hline Fish grouping & $\begin{array}{c}\text { Total } \\
\text { number }\end{array}$ & $\begin{array}{c}\text { Number of } \\
\text { dead fish }\end{array}$ & $\begin{array}{c}\text { Mortality } \\
\%\end{array}$ \\
\hline G(1) Infected non treated & 30 & 25 & 83 \\
$\begin{array}{l}\text { G(2) Infected and treated } \\
\text { with ciprofloxacin }\end{array}$ & 30 & 6 & 20 \\
$\begin{array}{l}\text { G(3)Infected and treated } \\
\text { with clove extract }\end{array}$ & 30 & 5 & 16 \\
$\begin{array}{l}\text { G(4)Infected and treated } \\
\text { with ciprofloxacin \& } \\
\text { clove extract }\end{array}$ & 30 & 4 & 13 \\
\hline
\end{tabular}

\section{Group 2: Catfish infected with $A$. sobria and treated with ciprofloxacin}

The liver showed hydropic degeneration and vacuolations in the hepatocytes (Fig 3). Congestion of the hepatic blood vessels and hemorrhage were rarely detected. 
The kidney revealed focal vacuolations in the tubular epithelium with activation in the hemopoietic cells (Fig 4).

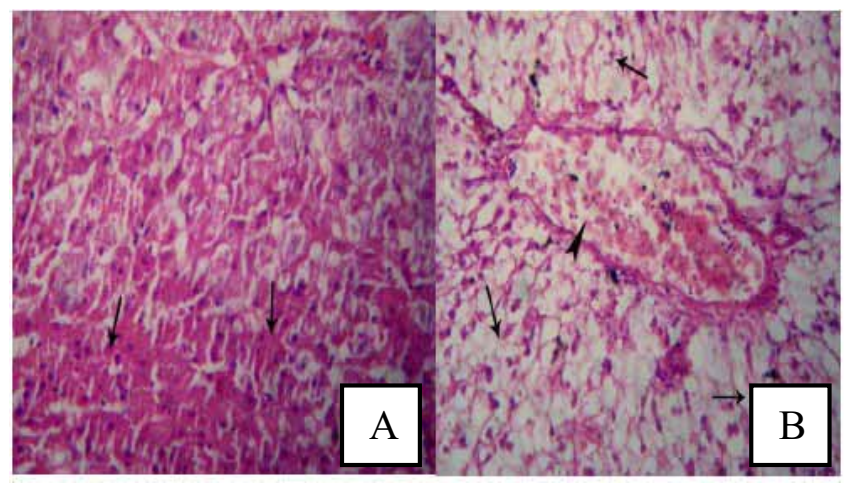

Figure 1: (A) Liver section of C.gariepinus from group (1) showing coagulative necrosis (arrows) and (B) showing congestion (arrowhead) and diffuse vacuolation of hepatocytes (arrows). (H\&E stain 40X).

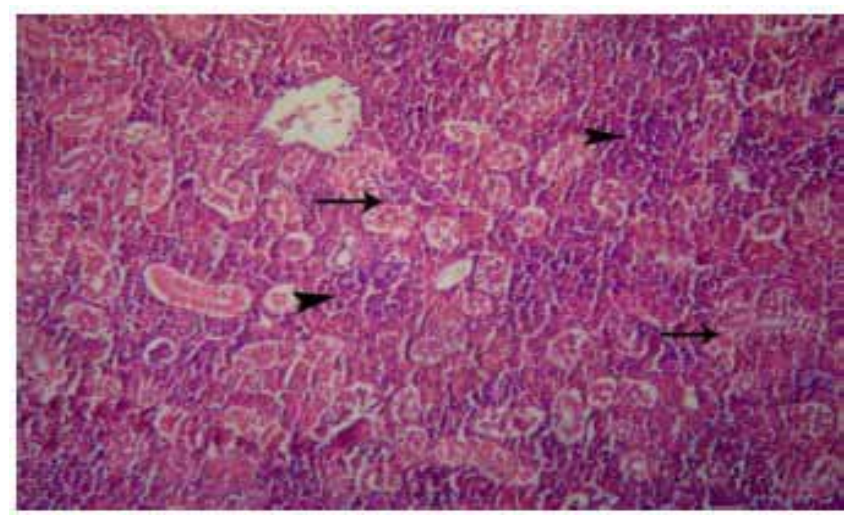

Figure 2: Kidney section of C.gariepinus from group (1) showing severe coagulative necrosis in the renal tubules (arrows) and depletion of hemopoietic elements (arrowheads). (H\&E stain 40X).

\section{Group 3 Catfish infected with Aeromonas sobria and treated with clove oil}

The liver revealed congestion of hepatic sinusoids beside diffuse hydropic changes in the hepatocytes and few leukocytes infiltration (Fig 5, A). Focal macrovesicular steatosis and coagulative necrosis were also noticed in the hepatocytes (Fig 5, B). The kidney showed focal areas of coagulative necrosis in the tubules with activation of the hemopoietic elements (Fig 6).

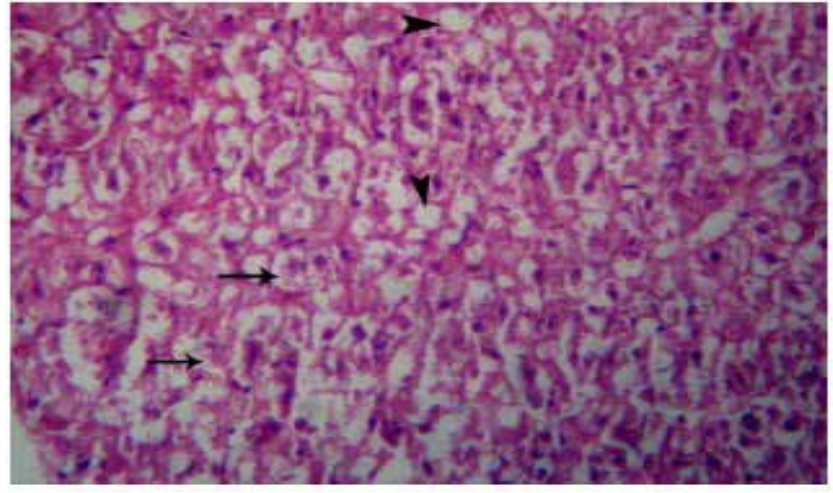

Figure 3: Liver section of Clarias gariepinus from group (2) showing hydropic degeneration and vacuolations in the hepatocytes (arrow). (H\&E stain 40X).

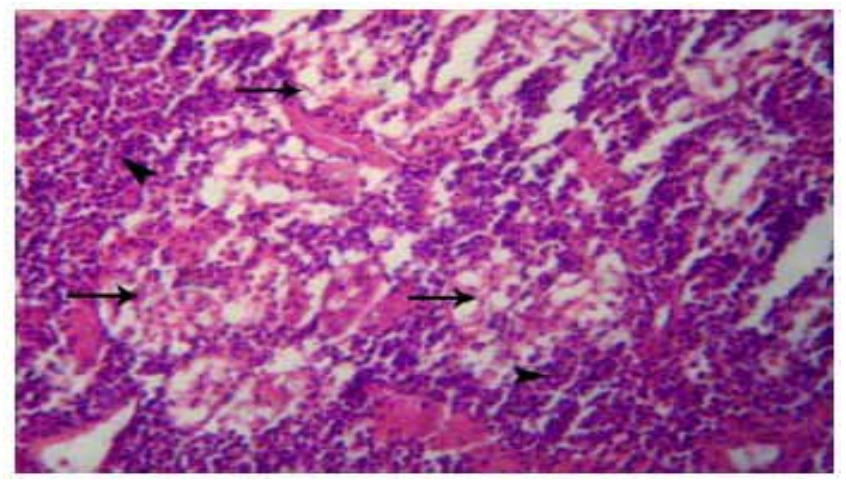

Figure 4: Kidney section of Clarias gariepinus from group (2) showing focal vacuolations in the tubular epithelium (arrow) and activation in the hemopoietic cells (arrowheads). (H\&E stain 40X).

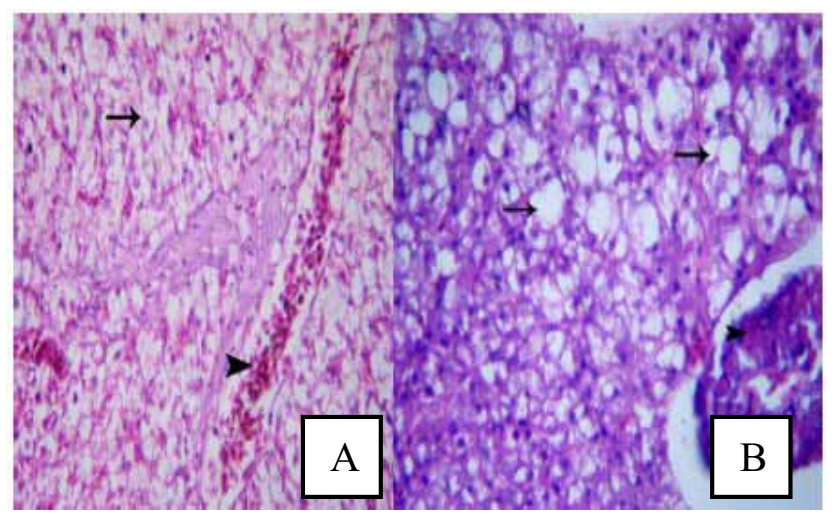

Figure 5: (A) Liver section of Clarias gariepinus from group (3) showing severe congestion (arrowhead) and vacuolations in the hepatocytes (arrows) and (B) showing macrovesicular steatosis (arrows). (H\&E stain 40X). 


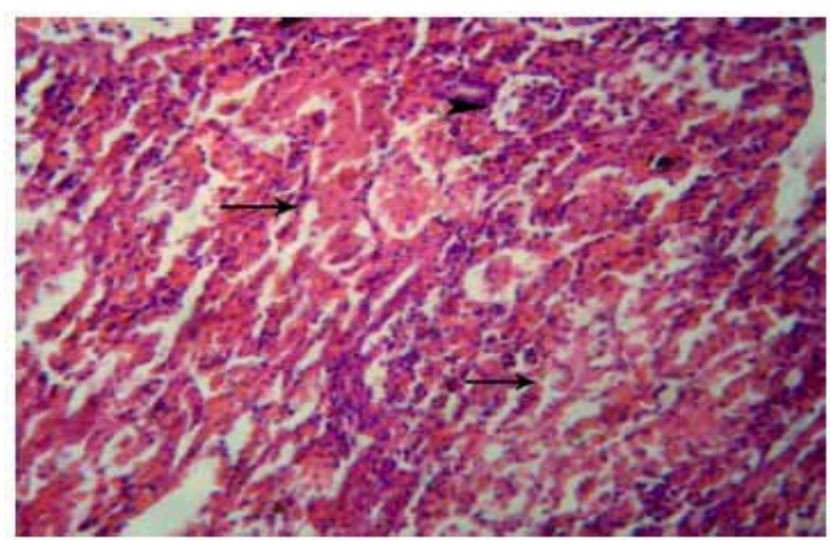

Figure 6: Kidney section of Clarias gariepinus from group (3) showing focal coagulative necrosis in the renal tubules (arrows) and activation of the hemopoietic elements. (H\&E stain 40X).

Group 4: Catfish infected with $A$. sobria and treated with the synergistic effect of ciprofloxacin and clove extract

The liver showed intact parenchyma with slight congestion, few interstitial and portal lymphocytes infiltration, focal hydropic degeneration and vacuolation of some hepatocytes (Fig 7). The kidney was normal except few focal vacuolation in the tubular epithelium (Fig 8). The fish infected with A.sobria and treated by both ciprofloxacin and clove extract were ameliorated than those infected with A.sobria and treated by either ciprofloxacin or clove.

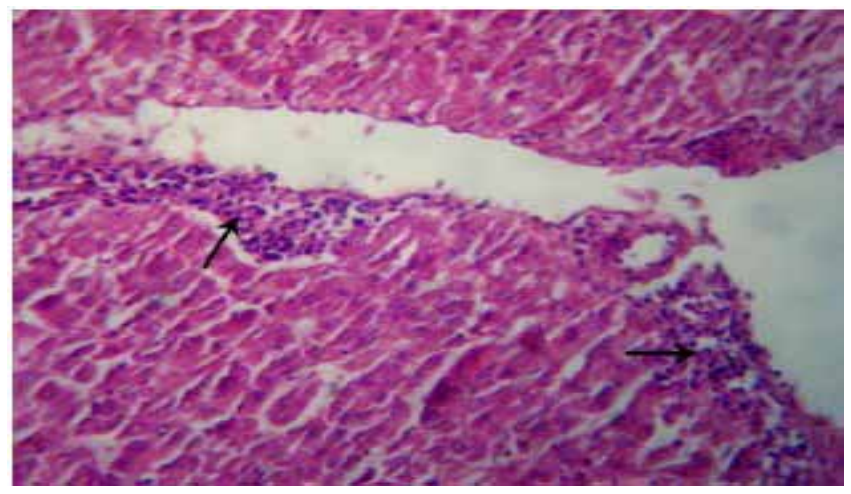

Figure 7: Liver section of Clarias gariepinus from group (4 showing few lymphocytes in the portal area (arrows). (H\&E stain $40 \mathrm{X})$.

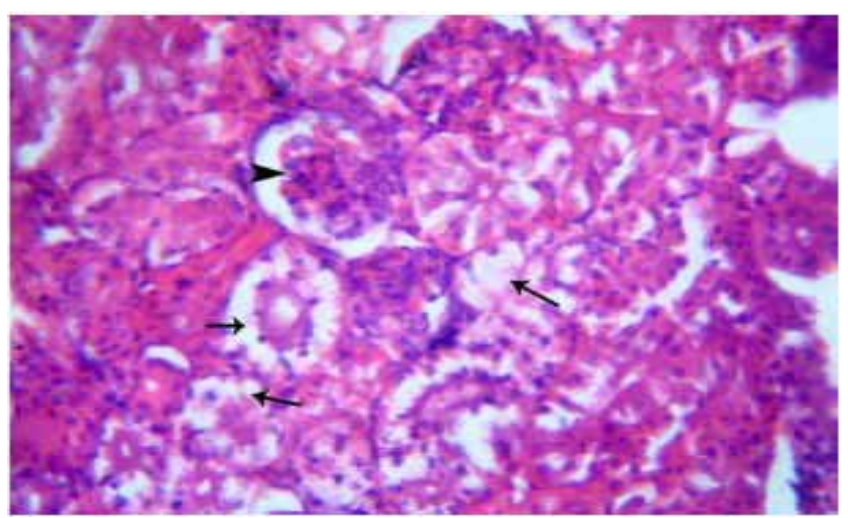

Figure 8: Kidney section of Clarias gariepinus from group (4) showing mild vacuolation in the tubular epithelium (arrows) and congested glomerulus (arrowheads). (H\&E stain $40 \mathrm{X})$.

\section{Discussion}

Mortality rate of $C$. gariepinus due to experimental infection of different isolates of Aeromonas spp. was varied. This variation of mortality rate was due to differences in the virulence among individual strains. The results were accordance with (18-22) which recorded that $A$. hydrophila produced mortality ranging from 0 to $100 \%$, while (23) recorded mortality rate in experimental infected carp fish by A. hydrophila (45\%) and reached to $100 \%$ in other fish species with the same isolates. The treated fish with ciprofloxacin (group, 2) increased the survival rate of fish challenged with $A$. sobria and in turn decrease the mortalities $(28,29)$, the treated by clove oil (group,3) showed they were milder than those in (group, 1) and ciprofloxacin and clove oil (group,4) was effective against MAS and the treated fish returned to the normal stats of health, our result was confirmed with those reported by (24-27). The results of treated with both ciprofloxacin and clove oil were nearly agreed with those reported by $(31,32)$ who clarified that the association of antibiotic and plant extract showed synergistic antibacterial activity especially with ciprofloxacin and erythromycin respectively.

The results of histological examination after staining with hematoxylin-eosin of the liver and kidney of Catfish infected with $A$. sobria and non-treated (group, 1) revealed coagulative necrosis, congestion and diffuse vacuolation of hepatocytes in liver and severe coagulative necrosis in the renal tubules and depletion of hemopoietic elements in kidney. The present data in current study was in agreement with study of (33-37). Liver section of C. gariepinus from (group, 2) showing hydropic degeneration and vacuolations in the hepatocytes and Kidney section of C.gariepinus showing focal vacuolations in the tubular epithelium and activation in the hemopoietic cells, this result corresponded 
with $(28,29)$ which indicated the ciprofloxacin increases the survival rate of fish challenged with A.sobria and in turn decrease the mortalities. Liver section of $C$. gariepinus from (group, 3) showing severe congestion, vacuolations in the hepatocytes and macrovesicular steatosis and the Kidney section of Clarias gariepinus) showing focal coagulative necrosis in the renal tubules, activation of the hemopoietic elements and the glomeruli were destructed with multifocal areas of hemorrhage (30). Liver section of C.gariepinus from (group, 4) showing few lymphocytes in the portal area and Kidney section of C. gariepinus showing mild vacuolation in the tubular epithelium and congested glomerulus, treated by either ciprofloxacin or clove as described by (31), (38) concluded that infected catfish mortality is due to typical histopathological lesions such as necrosis and atrophy of hepatocytes and necrosis of renal tubules and glomeruli in the kidney has occurred.

\section{Conclusion}

This result shows both ciprofloxacin and clove oil was the best choice as an alternative bacterial therapeutic agent in infected C. gariepinus with A.sobria. Since A. sobria may threaten human health, transmission of the reduced susceptibility may be having negative consequences for humans.

\section{Conflict of interests}

There are no conflicts of interest with regard to the present study.

\section{Reference}

1. Hariknishnan R, Nisha MR, Balasundaram C. Hematological and biochemical parameters in common carp (Cyprinus carpio) following herbal treatment for Aeromonas hydrophila infection. Aquaculture. 2003;221(1-4):41-50.

2. Francis-Floyd R. Aeromonas Infection EDIS Web Site at http://edis.ifas.ufl.edu. 2002.

3. Nam IY, d Joh K. Rapid detection of virulence factors of Aeromonas isolated from a trout farm by Hexaplex PCR. J Microbiol. 2007;297-304.

4. Rahman M, Patricia CN, KÜin I, Huys G, Swingm J, Möllby R. Identification and characterization of pathogenic Aeromonas veronii biovar sobria associated with Epizotic ulcerative syndrome in fish in Bangladesh. Appl Environm Microbiol. 2002;(68):650-655.

5. Wahli T, Burr SE, Pugovkin D, Mueller O. Frey J. Aeromonas sobria, a causative agent of disease in farmed perch, Perca fluviatilis L. Fish Dis. 2005;28:41-150.

6. Ciprianom RC, Bullock GL, Pyle SW. Aeromonas hydrophila and motile Aeromonad Septicemia of fish. Fish Disease Leaflet 68, US Department of the interior Fish \& Wildlife Service, Washington. 2001.

7. Huizinga HW, Esch GW, Hazen TC. Histopathology of Red-Sore Disease (Aeromonas hydrophila) in Naturally and Experimentally infected Largemouth Bass Micropterus salmoides (Lacepede). Inter J Microbiol 1979;92:275-287.

8. Buckely JT. Howard SP. The cytotoxic enterotoxin Aeromonas hydrophila is aerolysin. Infect Immun. 1999;67:466-467.
9. Min LIU, Ying HAN. Isolation and identification of Aeromonas sobria from infected carps and its sensitivity to drugs. J North Aquacul Univ. 2005.

10. Hatha M, Vivekanandhan AA, Julie Joice G, Christol. Antibiotic resistance pattern of motile Aeromonads from farm raised fresh water fish. Int J Food Microb. 2005;98:131-134.

11. Samar S, Negm. Microbiological and biochemical on freshwater fish under environmental stress". M. V. SC. A Thesis (Microbiology). Fac Sci Benha University. 2010.

12. Gülçin I, Elmastas M, Abou El-Enein HYZ. Antioxidant activity of clove oil. A powerful antioxidant source. Arabian J Chem. 2012;5:489-499.

13. Koneman EW, Allen SD, Janda WA. Guidelines for the collection, transport, processing, analysis and reporting of cultures from specific specimen sources. color atlas and textbook of diagnostic microbiology. Washington: Lippincott-Raven, 1997;pp:121-162.

14. Austin B, Austin DA. Bacterial fish pathogens, Disease of farmed and wild fish. Praxis publishing, UK 2007;pp: 581.

15. Brook I, Rogers J, Rollins DM, Coolbaugh JC, Walker RI. Pathogenicity of Aeromonas. J Infect. 1988;10(1):32-37.

16. Miles AA, Misra SS. Methods of counting bacteria by surface viable count. Yg Camb. 1983;38:732.

17. Carleton HM, Dury RAB, Wallington EA. Carleton Histological Technique. Forth Edition. 1967.

18. Sahoo PK, Meher PK, Mahapatra KD, Saha JN, Jana RK, Reddy PV. Immune responses in different fullsib families of Indian major crap, Labeo rohita, exhibiting differential resistance to Aeromonas hydrophila infection. Sci Direct Aquacul. 2004;238(1/4):115-125.

19. Wang-KaiYu. Pathological observations of bacterial septicemia in carp (Cyprinus carpio)". Journal-of-Sichuan-Agricultural University. 2004;22(3): 257-262.

20. Pan-Hou-jun, Wu-ShuQin, Dong-ChuanFu, Shi-CunBin, Ye-MeiXi, Lin-TianLong, Huang-ZhiBin. Identification, virulence, haemolytic activity of GYK1, a strain of pathogenic Aeromonas hydrophila isolated from mandarinfish Sinipera chuatsi. J Shanghai Fish Univer. 2005;13(1):23-29.

21. Rajeswari-Shome, Shome BR, Mazumder Y, Das A, Kumar A, Rahman H, Bujarbaruah KM. Abdominal dropsy disease in major carps of Meghalaya: isolation and characterization of Aeromonas hydrophila" Current-Science. 2005;88(12):1897-1900.

22. Jun JW, Kim JH, Gomez DK, Choresca Jr, CH, Han JE, Shin SP. and Park SC. Occurrence of tetracycline-resistant Aeromonas hydrophila infection in Korean cyprinid loach (Misgurnus anguillicaudatus)". Afr J Microbiol Res. 2010;4(9):849-855.

23. Dhanaraj M, Haniffa MA, Muthu RC, Arockiaraj AJ, Raman, S. S. and Singh, A. S. V. (2008): "Haematological analysis of common carp (Cyprinus carpio), gold fish (Carassim auratus), tilapia (Oreochromis mossambicus) and stinging catfish (Heteropneustes fossilis) spontaneously infected with Aeromonas hydrophila". Malaysian J Sci. 2010;27(1):61-67.

24. Abdalla OE, Selim MA. Comparison between tilmicosin and ciprofloxacin for controlling mycoplasma infection of broilers. Proc. The $1^{\text {st }}$ Intern Conf Vet Res Div. NRC, Cairo, Egypt. 2004;238-274.

25. Rahman T, Akanda MMR, Rahman MM, Chowdhury MBR. Evaluation of the efficacies of selected antibiotics and medicinal plants on common bacterial fish pathogens. J Bangladesh Agril Univ. 2009;7(1):163-168.

26. Thanikachalama K, Kasi M, Rathinam X. Effect of garlic peel on growth, hematological parameters and disease resistance against Aeromonas hydrophila African catfish Clarias garepinus (Bloch) fingerlings. Asian Pacific J. Trop Med. 2010;3(8):614-618.

27. Wafaa A, Ismail M. Tackling of experimental coliseaemia in broiler chickens using pytobiotic essential oils and antibiotic alone or in combination. Res J Poult Sci. 2013;6(3):59-67.

28. Nouws JF, Grondel JL, Schutte AR, Laurensen J. Pharmaco kinetics of ciprofloxacin in carp, African catfish and rainbow trout. Vet Q. 1988;10(3):211-216. 
29. Maisa MG. Efficacy of some antimicrobial in Oreochromis niloticus. Ph D Thesis (Pharmacology). Vet Med Zag. University. 1999.

30. Perez EE, Lewis EE. Use of Entomopathogenic nematodes and thyme oil to suppress plant parasitic nematodes on English box wood. Plant Dis. 2006;90(4):471-475.

31. Nascimento GG, Locatelli J, Freitas PC, Silva GL. Antibacterial activity of plant extracts and phytochemicals on antibiotic-resistant bacteria Braz J Microbiol. 2000; Oct./Dec. 3194. ISSN 1517-8382.

32. Abd El -Raouf A, Elmanama Amany A, Alyazji. Nedaa A, Abu Gheneima. Antibacterial, antifungal and synergistic effect of Lawsonia inermis, Punica granatum, Hibiscus sabdariffa. J Annals Alquds Med. 2011;7:33-41.

33. Austin B. Austin DA. Bacterial fish pathogens in disease in farmed and wild fish Ellis Horwood Ltd. Publisher, Chichester, England. 1993.
34. Deepak P, Katoch RC, Mahajan A, Mandeep S, Rajender P. Etiopathological investigations on clinical dropsy in carps (Cyprinus carpio) due to A.hydrophila in Himachal Pradesh. Indian J Ani Sci. 2002;72(2):197-199.

35. Laith RA, Najiah M. Aeromonas hydrophila: Antimicrobial Susceptibility and Histopathology of Isolates from Diseased Catfish, Clarias gariepinus (Burchell). J Aquac Res Devel. 2013;5:215.

36. Plumb JA, Sheifinger CC, Shryock TR, Goldspy T. Susceptibility of six bacterial pathogens of channel catfish to six antibiotic. J Aquat Anim Health. 1994;7:211-217.

37. Yildiz H, Bekcan S, KarasuBenli AC, Akan M. Some blood parameters in the eel (Anguilla anguilla) spontaneously infected with Aeromonas hydrophila. Isreal J Vet Med. 2005;60: 91-92.

38. Deivasigamani B. The immune response catfish, Mystus gulio. J Environ Biol. 2008;29(6):863-866. 